\title{
COMPUTER TOOLS TO DETERMINE PHYSICAL PARAMETERS IN WOODEN HOUSES
}

\author{
DOLOČANJE FIZIKALNIH PARAMETROV Z RAČUNALNIŠKIMI \\ ORODJI V LESENIH HIŠAH
}

\author{
David Bečkovský, František Vajkay, Vladimír Tichomirov \\ Brno University of Technology, Faculty of Civil Engineering, Institute of Building Structures, Veveři 95, 60200 Brno, Czech Republic \\ beckovsky.d@fce.vutbr.cz \\ Prejem rokopisa - received: 2013-10-01; sprejem za objavo - accepted for publication: 2015-06-30
}

doi:10.17222/mit.2013.213

\begin{abstract}
Nowadays, because the number of wooden houses gradually increases and due to European regulations, a huge emphasis is put onto the aspects like energy saving and energy efficiency in family housing, which are the topic of a related ongoing research project. Hence, the paper is focused on comparing and streamlining the methods available to the engineering community in the fields of energy consumption and air-tightness measurements of buildings. The newly developed design methodologies and practical outputs of the completed research project are planned to be delivered directly to the related industry. The research project is also focused on the humidity and temperature control in wooden houses since wooden houses consist of timber structural elements, whose humidity and moisture may later cause some liability-related problems. To prevent these failures, it is necessary to investigate the quality of tools and methodologies, through which one might determine the values of humidity and temperature already within the design phase. Nevertheless, design is only one phase of the whole process; the other is the building-realisation phase. Therefore, the questions to answer are: Who is actually responsible for the failures caused by humidity and moisture? When does the water actually penetrate the structural elements? Is it in the factory or when the elements are transported or when the products are stored at the construction site?

Keywords: moisture, wooden constructions, timber structures, energy consumption, Arduino, Raspberry Pi
\end{abstract}

Dandanes se zaradi naraščanja števila lesenih hiš in tudi zaradi evropske regulative posveča veliko pozornosti prihrankom pri energiji in energijski učinkovitosti družinskih hiš, kar je tudi predmet predstavitve. Članek je usmerjen na primerjavo in usmeritev metod, s katerimi razpolaga inženiring na področju porabe energije in meritev zrakotesnosti zgradb. Novo razvite metodologije načrtovanja in praktične rešitve iz raziskovalnih projektov bodo neposredno posredovane industriji. Raziskovalni projekt je usmerjen na kontrolo temperature in vlage $\mathrm{v}$ lesenih hišah, ker so lesene hiše zgrajene iz lesenih strukturnih elementov pri katerih lahko vlaga povzroči problem z zdržljivostjo. Za preprečevanje takih poškodb je potrebno preiskovati kvaliteto orodij in metodologij, s katerimi je mogoče oceniti vsebnost tako vlage kot temperature, in sicer že v sami fazi načrtovanja. Načrtovanje je samo ena od faz celotnega procesa, druga pa je faza gradbene realizacije. Vprašanje na katerega je potrebno odgovoriti je: kdo je $\mathrm{v}$ resnici odgovoren za poškodbe, ki jih povzroči vlaga in tudi kdaj voda v resnici penetrira v gradbene elemente? Je to že v tovarni, med transportom ali pa med shranjevanjem elementov na gradbišču?

Ključne besede: vlaga, lesena konstrukcija, leseni gradbeni elementi, poraba energije, elektronska platforma Arduino, Raspberry

\section{INTRODUCTION}

In the building industry, there are several variants of wooden houses. There are log-wood houses, woodenframe ones, wooden houses built from cross-laminated timber panels, etc. Nevertheless, the design procedure for wooden houses is the same as that for brickwork buildings and, among other measures, it must include a thorough thermal analysis ${ }^{1}$ since the durability and functionality of modern wooden structures depend on the humidity and moisture control. In the case of wooden houses, it is crucial to avoid condensation of water vapour in the building envelope. This affects the thermotechnical requirements given to designed structures, especially those of wall and roof cladding. The design of peripheral wall and roof cladding must also properly solve all the details, including the quality of designed materials.
However, even if the design incorporates all the design principles, there is still no guarantee that the designed structures are going to function properly when built under real-life conditions because some failures might appear during the building erection process. That is why construction works have to be regularly inspected by the construction inspector and the technical supervisor of the investor.

Supervision and monitoring throughout the construction process ensure the highest quality of the provided services and reduce the formation of defects, primarily when structural materials and elements are built in, since the initial water content can cause some problems as well. The initial water content should be checked and compared to the numbers contained in the "Technical Data Sheets" published by the manufacturers. 


\section{CONTAMINATION DURING THE EXECUTION}

The issue of the initial mass moisture is demonstrated by T. Kalábová et al. ${ }^{2}$ on mineral-fibre thermal-insulation panes, which were built into the timber joist ceilings of the EXDR1 experimental wooden house.

Within the discussed timber joist ceilings, the space between the joists is completely filled with mineral-fibre thermal-insulation boards. The built-in boards were delivered under rainy-weather conditions in summertime and were left outside to ventilate for a period of 14 days before they were unpacked and used.

Although the building material was delivered in its original packaging in shrink-wrap foils, some of the mineral-fibre boards had a significant amount of moisture content.

The moisture inside was verified with an infrared imaging camera after positioning the first layers of the thermally insulating mineral-fibre boards. Hot spots of moisture content above $70 \%$ were localized at several locations (Figure 1).

With an infrared imaging camera, it is possible to:

- Determine the distribution of the surface temperature over the envelope or the distribution of the apparent radiant temperature;

- Determine the distribution of the atypical surface temperature, i.e., the temperature changes caused by some disorders such as the moisture content, insulation, or penetration of air;

- Assess the type and extent of the problem.

To determine whether the observed changes were atypical or not, the obtained thermographs were compared to the expected distributions of surface temperatures determined experimentally under the same boundary conditions in the form of building-shell variables. The estimated temperature distributions can be determined either from reference thermographs, with calculations or surveys as another possibility.

\subsection{Sensing devices - a thermal imager}

To take infrared images, it is necessary to fulfil one condition, which is a large temperature difference bet-

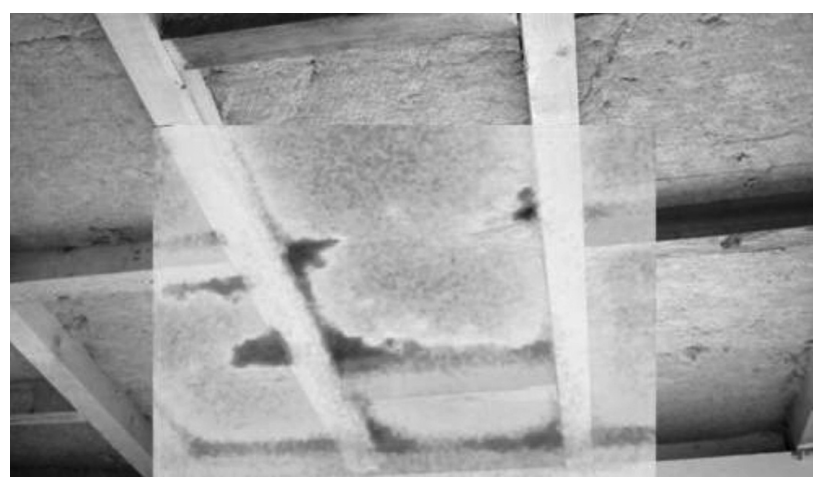

Figure 1: Moisture in the ceiling structure

Slika 1: Vlaga v konstrukciji stropa

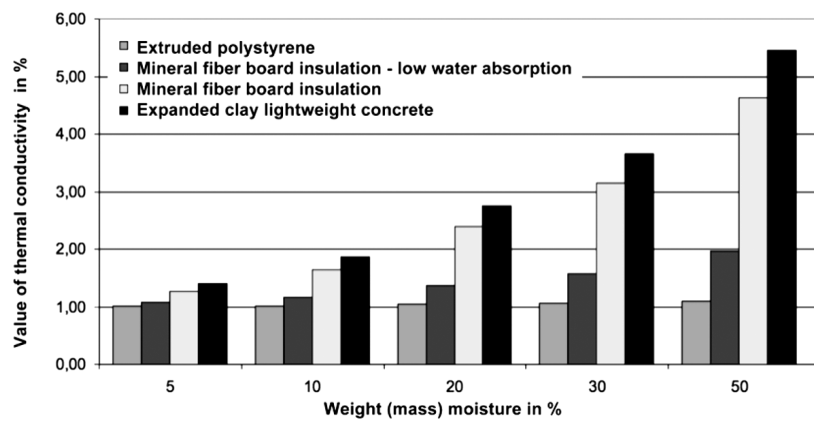

Figure 2: Thermal conductivities of different thermally insulating materials under varying moisture content

Slika 2: Toplotna prevodnost različnih materialov za toplotno izolacijo, pri različnih vsebnostih vlage

ween the inside and the outside of an envelope. The temperature difference must be big enough to allow the detection of thermal irregularities. The test cannot be conducted if the external or internal temperature varies considerably or if the structure is exposed to direct sunlight.

\section{MOISTURE PREVENTION}

One way to prevent the incorporation of moisture in wood-based materials susceptible to higher levels of humidity is a control mechanism and a procedure, such as the usage of stick hygrometers or infrared imaging cameras.

An application of wet materials in the course of the construction process can lead to a rapid appearance and development of wood-decaying organisms, which are very difficult and expensive to dispose of. One way for the disposal of wood-decaying organisms is to use microwave radiation, ${ }^{3}$ where electromagnetic waves oscillate at frequencies of $300 \mathrm{MHz}$ to $300 \mathrm{GHz}$. These frequencies correspond to wavelengths of $1 \mathrm{~m}$ to $1 \mathrm{~mm}$. The microwave generator is completely safe to use if treated with care. Health issues can arise only due to a long-term direct exposure from a close distance.

\section{MONITORING DURING THE LIFE CYCLE}

The monitoring of the physical parameters of the structures and internal environment of buildings brings significant investment costs as a large number of various sensors and data loggers are required to make such a monitoring possible. Due to individual requirements of research teams and the restlessness of developers of computing hardware and information technologies, the authors of the article (themselves researchers in the field of building physics) came up with an idea and decided to build a custom data logger with a high variability of connectable parts and sensors. The whole process is based on do-it-yourself prototyping. The data logger is made of two prototyping boards, which are cheap and relatively easy to use. Using ArduPi, it consists of a 


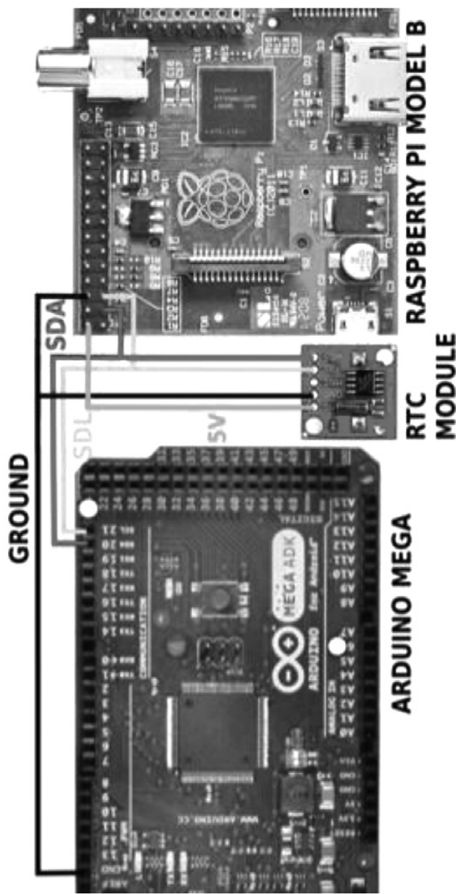

Figure 3: I2C data line between Raspberry Pi, RTC module and Arduino board

Slika 3: I2C podatkovna linija med Raspberry Pi, RTC modulom in Arduino platformo

credit-card-sized ARM-processor-based Raspberry Pi model B and an open-source microcontroller board Arduino (the correct description of the board is Arduino Mega 2560).

The boards can communicate via USB (universal serial bus), I2C (inter-integrated circuit communications) or SPI (serial peripheral interface) interfaces. ${ }^{4} \mathrm{~A}$ realtime clock module can be coupled to them as well as any of the available sensors. Thus, even after a power outage, the system is able to resume the task given to it.

\subsection{Reasoning behind the choice of the boards}

Both boards, the Raspberry Pi and the Arduino, were chosen because they can be programmed for different purposes. Both of them have a huge number of GPIO (general-purpose input/output) headers starting with USB ports and ending with analogue voltage input pins. The boards can communicate throughout the by-directional I2C communication protocol. ${ }^{5}$ To avoid data and speed losses, it is recommended to use a shielded cable between the two boards. Nonetheless, a by-directional voltage divider is a requirement for the $\mathrm{I} 2 \mathrm{C}$ communication. The Raspberry Pi I2C interface works at $3.3 \mathrm{~V}$, while the Arduino interface works at $5 \mathrm{~V}$.

The Raspberry Pi is cheap and the first of its kind. The ARM processor with a clock speed of $700 \mathrm{MHz}$ can run different processes. Thus, the Raspberry Pi can be used as a PC with Raspbian OS (a modification of Debian Linux OS) running on it. It can be hooked up with a keyboard, a mouse and a display and can run a web and

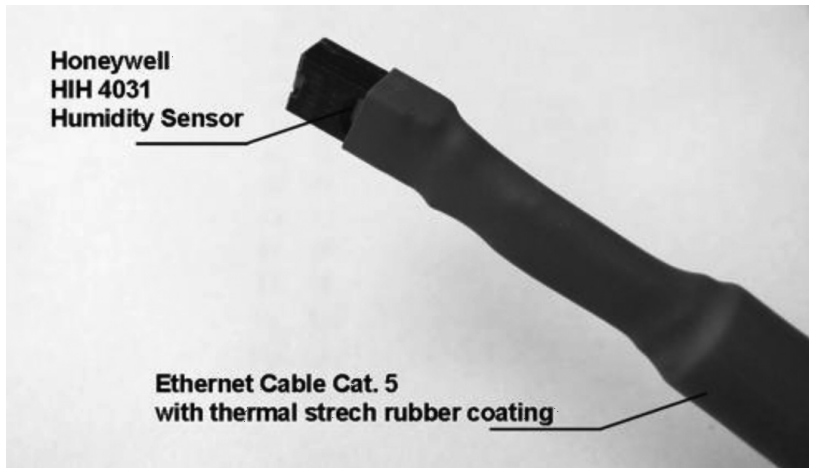

Figure 4: Close-up view of the HIH-4031 sensor Slika 4: Podrobnejši pogled na HIH-4031 senzor

SQL server as well as displaying data. With Python ${ }^{6,7}$ scripting possibilities, it is suited to be used as the brain of the ArduPi.

Even though it would be possible to operate most of the sensors (1-Wire, I2C, SPI) with the Raspberry Pi, the Arduino board can do it better. Arduino boards have a 10-bit internal ADC (analogue-to-digital converter). Analogue sensors for the measurement of relative humidity, like the Honeywell HIH-4031, output electricity in place of digital data. Such readings need to be converted.

One could use ADC integrated circuits instead of an Arduino board. Nonetheless, Arduino is preferred because it can be easily programmed in the bundled IDE (Integrated Development Environment). ${ }^{8}$

\subsection{Used sensors}

When researching an indoor environment, we need to have a relatively large number of sensors: some thermal couples, relative-humidity sensors and others. The sensors that can be obtained for a reasonable price are produced by companies like Honeywell, Dallas Instruments, Panasonic and may be digital or analogue. Just to mention, the prototype of ArduPi utilizes the already mentioned analogue humidity sensors HIH-4031 (Figure 4) by Honeywell.

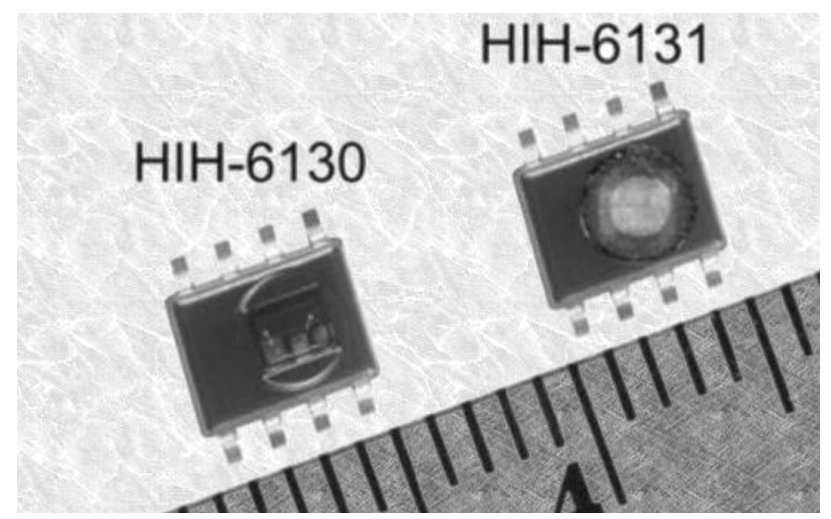

Figure 5: Close-up view of HIH-613X products

Slika 5: Podrobnejši pogled na HIH-613X proizvode 


\section{BEČKOVSKÝ et al.: COMPUTER TOOLS TO DETERMINE PHYSICAL PARAMETERS IN WOODEN HOUSES}

To free up the analogue input pins on the Arduino board for different sensors, the usage of combined digital sensors HIH 6131-021 is planned (Figure 5). These sensors are also made by Honeywell.

These sensors communicate via the already mentioned I2C communication protocol.

Energy-consumption sensors are important for monitoring an internal environment as, in the case of a power failure, they immediately record the time without electricity. Information about such conditions can be instantly delivered by GPRS or EDGE.

Analogue pins for mFi-CS sensors are available from Ubiquiti Networks and used for monitoring the energy consumption of home appliances and many others.

\section{CONCLUSIONS}

With the modern technologies and materials available, it is possible to put together small and cheap data loggers for experimental purposes to be used in building physics instead of the ones produced by one of the major companies. Data loggers may be customized to the needs of the user, including the software base for the operation. The choice of sensors and measuring equipment depends solely on the user. Whether the sensors hooked up are going to have an accuracy of $0.5 \%$ or $5 \%$ depends only on the available funds. The only requirement is their compatibility to any of the supported communication protocols. It can be said that the creation of BRESET on an ArduPi base is a major step as it brings the possibilities of research activities closer to the scientific community.

\section{Acknowledgement}

This paper was completed under project no. LO1408 "AdMaS UP - Advanced Materials, Structures and Technologies", supported by the Ministry of Education, Youth and Sports under the National Sustainability Programme I and under the Project FAST-S-15-2757 supported by Ministry of Education, Youth and Sports under "Specific University Research".

\section{REFERENCES}

${ }^{1}$ P. Charvat, T. Mauder, M. Ostry, Simulation of Latent-Heat Thermal Storage Integrated with Room Structures, Mater. Tehnol., 46 (2012), 239-242

${ }^{2}$ T. Kalábová, M. Horáčková, F. Vajkay, Experimental timber framed house EXDR1, Advanced Materials Research, 649 (2013), 73-76, doi:10.4028/www.scientific.net/AMR.649.73

${ }^{3}$ M. Novotný, J. Škramlík, K. Šuhajda, J. Sobotka, J. Gintar, T. Kalábová, Efficiency of liquidation of biotic pests using microwave radiation, Advanced Materials Research, 688 (2014), doi:10.4028/ www.scientific.net/AMR.688.27

${ }^{4}$ S. C. Russell, Raspberry Pi \& Arduino, The MagPi, 7 (2012), 4-6

${ }^{5}$ L. Oscar, Raspberry $\mathrm{Pi}$ and Arduino Connected Using I2C, http://blog .oscarliang.net/raspberry-pi-arduino-connected-i2c

${ }^{6}$ Jaseman, The Python pit, The MagPi, 1 (2012), 23-29

${ }^{7}$ M. Summerfield, Programming in Python 3, Pearson Education 1td., Boston 2009

${ }^{8}$ M. Banzi, Getting started with Arduino, O'Reilly Media Inc., Sebastopol 2008 